\section{Prioritizing research at the Canadian Thoracic Society and beyond}

Tam fortunate to inherit the Canadian Thoracic Society (CTS) Presidency at a time when the CTS is stronger than it has ever been. Thanks to my predecessors, the CTS - at 52 years - is mature and growing. It has a strategic plan, a more robust administrative infrastructure to support that plan and is developing a new governance structure fully aligned with strategic priorities. At this juncture, it is clear to me that the CTS is ready to meet one of its newest challenges - strengthening its own research program while guiding the development of a national respiratory research agenda.

In a recent poll conducted by the CTS, the directors of academic respiratory divisions across the country overwhelmingly indicated their concern regarding the current erosion of clinical research in Canada and the progressive decline in funding, infrastructure and training opportunities. Urgent steps need to be taken to address these very real concerns and to preserve our welldeserved reputation for excellence in clinical research in respiratory diseases.

A great deal of work has already been completed on the research file, primarily through the following two meetings:

Research meeting - June 2009

A small group of CTS leaders and members with research expertise met in Winnipeg (Manitoba) to review the state of respiratory research in Canada. As a result of this preliminary discussion, Drs Shawn Aaron and Andrew Halayko agreed to co-chair the CTS Research Steering Committee. This interim Steering Committee's initial responsibilities were to identify key interim priority research areas for the CTS research program and plan a national research meeting in the fall, when a broader range of key stakeholders would be invited.

National meeting - November 2009

In collaboration with the Canadian Institutes of Health Research (CIHR) Institute of Circulatory and Respiratory Health, the University of Manitoba (Winnipeg, Manitoba) and the Canadian Lung Association (CLA), the CTS hosted a two-day meeting to launch the process of developing a national respiratory research agenda. The two-day meeting consisted of a scientific symposium, 'The State of the Art: Pulmonary Medicine Research in Canada', hosted by the University of Manitoba Faculty of Medicine, and a full-day facilitated meeting that focused specifically on the national respiratory agenda.

We were fortunate to have distinguished speakers deliver presentations on a number of key themes to help enrich our discussions regarding the development of a national respiratory agenda:

The state of respiratory research and respiratory disease in Canada

- Jessica Evans, of the Public Health Agency of Canada, brought us up to speed on the burden of respiratory diseases in Canada.

\section{Prioriser la recherche à la Société canadienne de thoracologie et au-delà}

\begin{abstract}
T'ai la chance d'hériter de la présidence de la Société canadienne de thoracologie (SCT) à un moment où cette dernière est plus forte que jamais. Grâce à mes prédécesseurs, la SCT, après 52 ans d'existence, est arrivée à maturité et continue de croître. Elle s'est dotée d'un plan stratégique, d'une infrastructure administrative plus solide pour le soutenir, et elle met au point une nouvelle structure de gouvernance qui est entièrement en phase avec ses priorités stratégiques. À ce carrefour, il m'apparaît clair que la SCT est prête à relever ce nouveau défi, c'est-à-dire, consolider son propre programme de recherche tout en orientant la préparation d'un agenda de recherche national sur les maladies respiratoires.

Lors d'un récent sondage réalisé par la SCT, les directeurs des départements de pneumologie des facultés de médecine du pays se sont dits très inquiets de l'érosion actuelle de la recherche clinique au Canada et du déclin progressif de son financement, de ses infrastructures et des possibilités de formation dans ce domaine. Des mesures urgentes s'imposent pour redresser cette situation très préoccupante et pour préserver notre réputation bien méritée d'excellence en recherche clinique sur les maladies respiratoires. Beaucoup de travail a déjà été fait dans le dossier de la recherche, surtout lors des deux rencontres suivantes :
\end{abstract}

\section{Rencontre sur la recherche - juin 2009}

Un petit groupe de responsables et de membres de la SCT spécialistes de la recherche se sont réunis à Winnipeg (Manitoba) pour faire le point sur l'état de la recherche sur les maladies respiratoires au Canada. Suite à ces discussions préliminaires, les docteurs Shawn Aaron et Andrew Halayko ont accepté de coprésider le comité directeur de la SCT pour la recherche. Ce comité directeur intérimaire avait pour responsabilité initiale d'identifier les principales avenues de recherche prioritaires pour le programme de recherche de la SCT et de planifier une rencontre nationale sur le sujet à l'automne, alors que d'importants intervenants de divers horizons allaient être invités.

\section{Réunion nationale - novembre 2009}

En collaboration avec l'Institut pour la santé circulatoire et respiratoire des Instituts pour la recherche en santé du Canada (IRSC), l'Université du Manitoba (Winnipeg, Manitoba) et l'Association pulmonaire canadienne (APC), la SCT a tenu une réunion de deux jours pour lancer le processus d'élaboration d'un agenda de recherche national sur les maladies respiratoires. Cette rencontre prévoyait la tenue d'un symposium scientifique sur la fine pointe de la recherche en médecine pulmonaire au Canada, dont la faculté de médecine de l'Université du Manitoba était l'hôte; le lendemain, la journée entière a été spécifiquement consacrée au programme national de recherche sur les maladies respiratoires.

Nous avons eu la chance de pouvoir compter sur des conférenciers de renom qui ont abordé des thèmes importants et ont ainsi alimenté nos discussions au sujet du développement d'un agenda national de recherche sur les maladies respiratoires:

Le point sur la recherche et sur les maladies respiratoires au Canada

- Jessica Evans, de l'Agence de santé publique du Canada, nous a éclairés sur le fardeau des maladies respiratoires au Canada. 
Federal research funding and opportunities

- Dr Peter Liu, of the CIHR Institute of Circulatory and Respiratory Health, provided us with an update on the institute's priorities, the programs it funds and the opportunities it offers.

- Anne Van Dam, of the CTS and the CLA, presented an overview of CTS/CLA research programs.

\section{The British experience}

- Dr Stephen Holgate, Medical Research Council, United Kingdom, provided an overview of the British experience in creating a resilient national research agenda.

\section{Partnerships}

- Dr Arnold Naimark from the University of Manitoba, provided expert guidance on the development of successful partnerships.

- Professor Éric Rousseau provided an example of a successful provincial respiratory network.

During the next year, we will build on the work that was completed at the June and November meetings. The results of these two meetings will be distilled and an action plan developed. The Research Steering Committee is in the process of establishing its terms of reference to guide its future activities, which will no doubt centre on two main goals:

- To develop, disseminate and evaluate a national respiratory agenda, in collaboration with key stakeholders; and

- To develop a strategic and integrated CTS research program aligned with the priorities of the national respiratory research agenda.

The CTS Executive, the Board of Directors and I fully support the efforts of the Research Steering Committee. Research will be featured on the agenda of every meeting of the CTS Board and Executive, and will have the prominence it deserves as a key committee within the new CTS governance structure. We will also ensure that our own internal infrastructure, at both the CTS and CLA, provides the necessary resources to sustain a strong research program and support development of the national agenda.

Research is a cornerstone of all activities in respiratory health. It serves as the foundation for guidelines development, which, in turn, constitutes the foundation for evidence-based care, whose outcomes feed back into the cycle and serve as the basis for new research. By building a strong respiratory research program within the CTS and aligning it with a robust national respiratory agenda, the CTS will be better able to perform its mission and improve respiratory health in Canada.

I offer my sincere thanks to Research Steering Committee cochairs, Andrew Halayko and Shawn Aaron, as well as to all committee members for their commitment to this most important endeavour. Many thanks as well to Dr Peter Liu and the CIHR Institute of Circulatory and Respiratory Health, and to the University of Manitoba for their support and collaboration. We look forward to continuing to work with them and other stakeholders from across the country on developing and implementing a national respiratory research agenda. I also extend my appreciation to Janet Sutherland, CTS Director, Anne Van Dam, Research Director, and Michelle McEvoy, Research Manager, for their ongoing support.

Together, we are making a difference in respiratory health!

Respectfully submitted, Denis E O'Donnell MD FRCPI FRCPC President, Canadian Thoracic Society
Financement fédéral de la recherche et possibilités

- Le Dr Peter Liu, de l'Institut pour la santé circulatoire et respiratoire des IRSC, a fait le point sur les priorités de l'Institut, les programmes qu'il subventionne et les possibilités qu'il offre.

- Anne Van Dam, de la SCT et de l'APC, a présenté un survol des programmes de recherche de ces deux organismes.

\section{L'expérience britannique}

- Le Dr Stephen Holgate, du Medical Research Council du RoyaumeUni, a fourni une vue d'ensemble de la façon dont le Royaume-Uni s'y est pris pour se doter d'un agenda national de recherche.

\section{Partenariats}

- Le Dr Arnold Naimark, de l'Université du Manitoba, a partagé avec nous son expertise dans l'établissement de partenariats fructueux

- Le professeur Éric Rousseau a présenté un exemple de réseau provincial efficace dans le domaine des maladies respiratoires.

Au cours de l'année à venir, nous tablerons sur le fruit des rencontres de juin et de novembre. Nous analyserons les résultats de ces deux rencontres afin d'en tirer un plan d'action. Le comité directeur est en voie d'établir son mandat pour guider ses activités futures, qui seront sans contredit axées sur les deux principaux objectifs suivants :

- Développer, diffuser et évaluer un agenda national pour la recherche sur les maladies respiratoires en collaboration avec les principaux intervenants; et

- Mettre au point un programme de recherche stratégique sur les maladies respiratoires intégré à la SCT et concordant avec les priorités de l'agenda national.

L'exécutif, le conseil d'administration de la SCT et moi-même appuyons entièrement les efforts du comité directeur. La recherche figurera à l'ordre du jour de toutes les réunions du conseil et de l'exécutif de la SCT, et le comité recevra toute l'attention qu'il mérite en tant qu'élément clé de la nouvelle structure de gouvernance de la SCT. Nous nous assurerons également que notre propre infrastructure interne, tant à la SCT, qu'à l'APC, puisse offrir les ressources nécessaires pour soutenir un programme de recherche fort et promouvoir la mise au point de l'agenda national.

La recherche est la clé de voûte de toutes les activités en santé respiratoire. Elle sert de base à l'élaboration des lignes directrices; ces dernières constituent le fondement des approches thérapeutiques fondées sur des preuves et en retour, le résultat de ces approches thérapeutiques est pris en compte dans le cycle global et sert à nouveau de piste exploratoire. En établissant un programme de recherche solide sur les maladies respiratoires au sein de la SCT et en le faisant concorder avec un agenda national bien structuré, la SCT sera en meilleure position pour réaliser sa mission et améliorer la santé respiratoire au Canada.

J'adresse mes sincères remerciements aux coprésidents du comité de direction pour la recherche, Andrew Alayko et Shawn Aaron, et à tous les membres du comité pour leur dévouement à l'endroit de cet important projet. Je tiens à souligner également l'appui et la collaboration du Dr Peter Liu, de l'Institut pour la santé circulatoire et respiratoire des IRSC, et à l'Université du Manitoba. Nous sommes heureux de pouvoir continuer à travailler avec eux et avec d'autres intervenants des quatre coins du pays pour l'élaboration et la mise en œuvre de l'agenda de recherche national sur les maladies respiratoires. Je remercie aussi Janet Sutherland, directrice de la SCT, Anne Van Dam, directrice de la recherche, et Michelle McEvoy, gestionnaire de recherche, pour leur appui soutenu.

Ensemble, nous améliorons bel et bien la santé respiratoire!

Salutations distinguées, Denis E. O'Donnell, M.D., FRCPI FRCPC Président, Société canadienne de thoracologie 


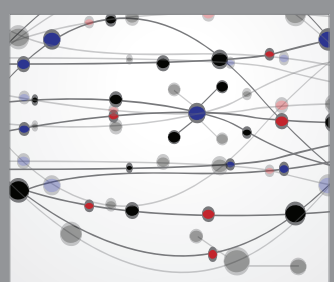

The Scientific World Journal
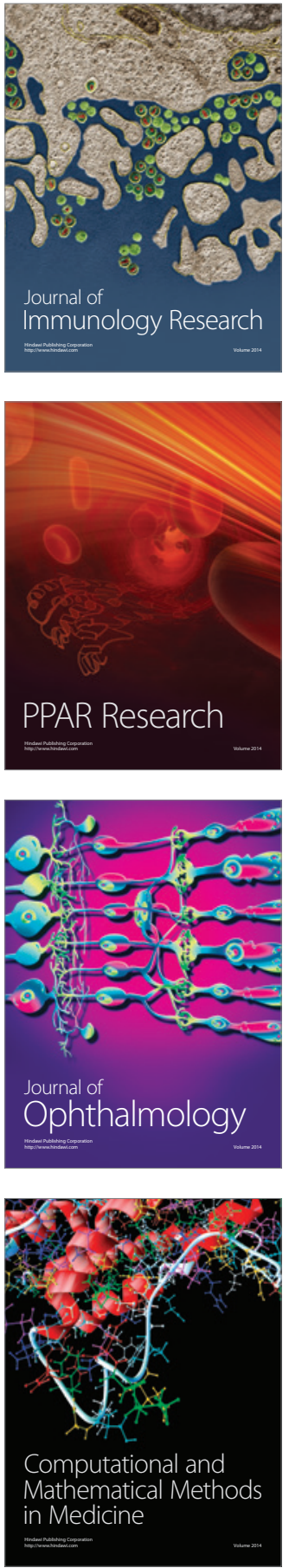

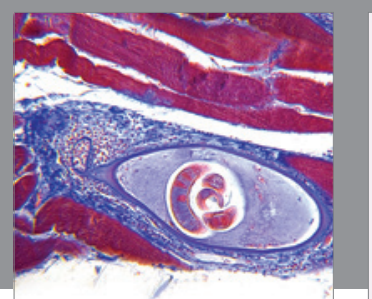

Gastroenterology Research and Practice

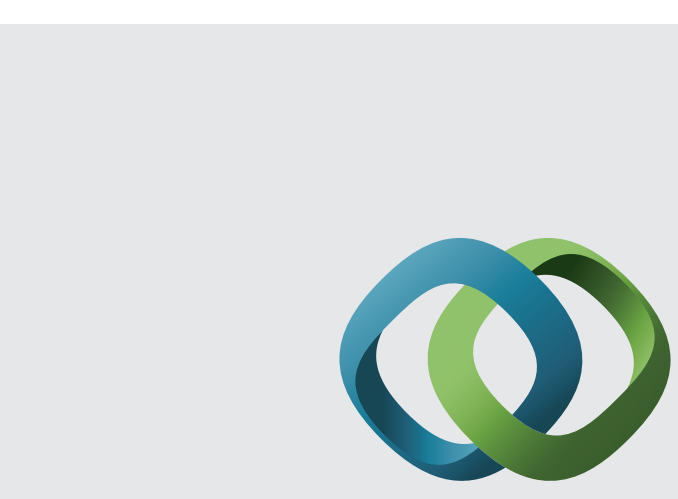

\section{Hindawi}

Submit your manuscripts at

http://www.hindawi.com
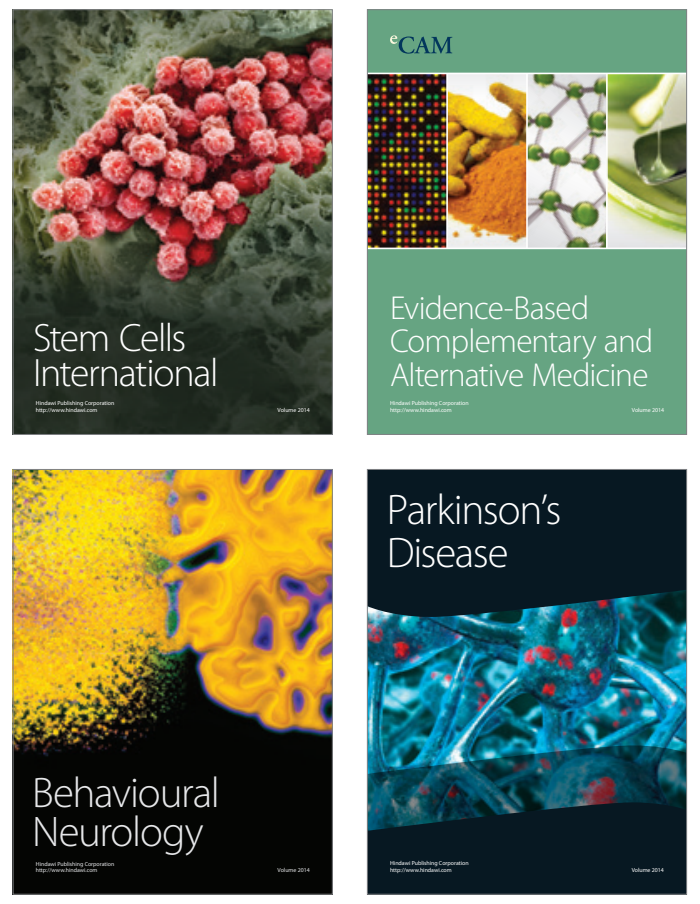
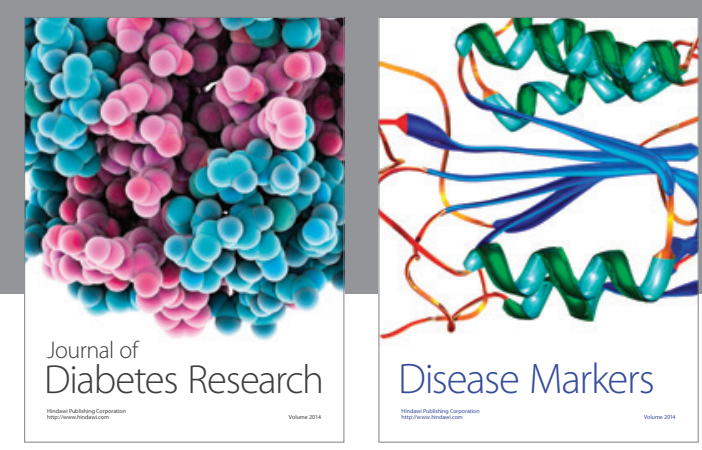

Disease Markers
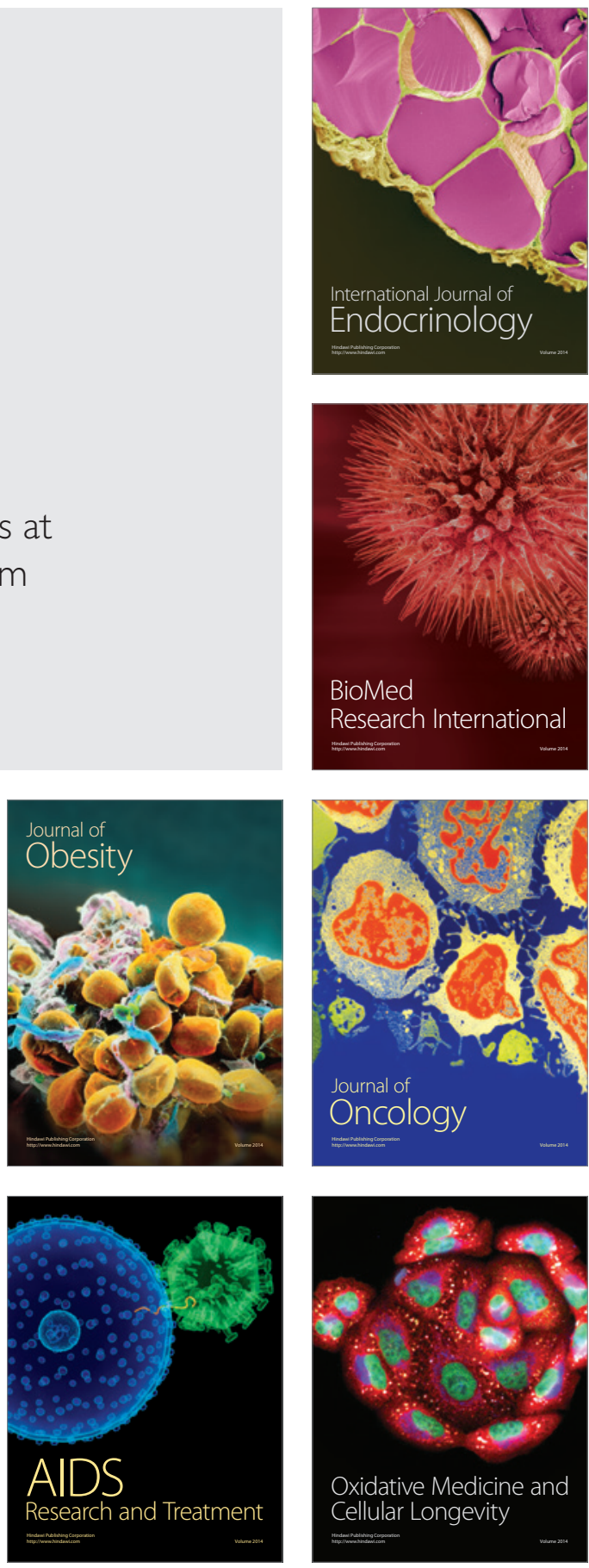